\title{
The Harvard University Archives
}

\author{
$A$ paper read by $C$. K. Shipton, custodian \\ of the Harvard University archives, before \\ the Boston meeting of the Archives and \\ Libraries Committee of the American Li- \\ brary Association.
}

$\mathrm{B}$ Y REASON of age and relatively large size, Harvard University has had certain experiences in regard to the accumulation, the preservation, and the servicing of her archives which may be guides, or horrid warnings, to the archivists of her younger sisters. The Harvard archives collection began as a row of record books which the president probably kept on a shelf in his study; they were there, fortunately, when the library burned in 1764 . Two generations later President Sparks, perhaps as a result of the interest aroused by the two hundredth anniversary of the founding of the college, gathered such loose papers relating to the college as he could find and had them bound and placed in the library. Some time before the Civil War the volumes of records were brought from the president's house and placed in the library beside those gathered by Sparks. This shelf of twenty volumes or so has in eight years grown into a collection of twenty-six thousand volumes, bundles, and boxes of both print and manuscript. How many pieces of manuscript this collection contains, no man knoweth, but it occupies several times as many cubic feet as other collections which are estimated by their curators to contain a half million pieces.
The Harvard archives consist, primarily, of those records of the university which are old enough not to be in active administrative use. Where current files are placed in our care, the administrative office keeps copies for its daily use. The board of overseers, the corporation, the faculty, and each school, division, department, laboratory, museum, committee, and similar organization, accumulates minutes, correspondence, files of routine records, and committee records, all of which the university archives gathers into its ample bosom. The older files of minutes run unbroken over periods which make the lives of civil governments seem transitory. The records of the overseers begin with the meeting of May 6, I650; those of the corporation, on December I0, 1654 ; and those of the faculty, on October 30 , I 725, when that body first began to keep minutes. Less complete are the files of the correspondence of the presidents, secretaries, deans, and other administrative officers. The papers of President Eliot, the largest file of this character, fill 365 boxes. The series of manuscripts of lectures delivered on endowed foundations begins with the first in 1755 , and the file of exhibition parts and winning prize essays begins in 1789 and 1808 . Among these are the early essays and poems of many a lad later famous in American letters; Charles Sumner, as early as 1832, was enquiring whether the most important changes in society are effected gradually or by violent revolution. All of the politi- 
cal, literary, and scientific questions of the day are argued here with youthful vigor.

The records of commencement exercises begin with a contemporary list of the theses argued by the candidates of 1643 and continue through the programs of the present day. Step by step these topics show the unfolding of every branch of human knowledge over almost three centuries. Unfortunately the early presidents did not keep copies of the students' commencement parts beside the record books on the study shelf, so the earliest manuscript text of such exercises is one of 1750 , but since 1825 the file is nearly complete. A sample of the possibilities which this collection offers for research is that part in which the young Thoreau argued the effect of the commercial spirit on the character of a nation. Of the orations with which dignitaries have enlightened the audience on commencement day, we have fewer, but the first is one delivered in 1649 . The earliest salutatory and valedictory orations are those of 1697 .

The files of examination questions and of doctoral dissertations go back to the introduction of these two institutions of American college life and are almost complete. Of recent years we have also kept the theses for the bachelors' degree as well. Of the many university publications which grace our shelves in their official files, the Nestor is the catalog of graduates which, born in 1674 , died of its own obesity in 1930, when the record for the longevity of periodicals was within its grasp.

\section{Criterion of Inclusion}

As this galloping survey of the contents of the Harvard archives indicates, the criterion of inclusion is relationship to the university; we make no distinction between manuscript and printed material.
The common custom of lumping all of the diverse manuscripts of a library under the term "archive" and treating them as a single collection has its disadvantages. The problems of collecting, organizing, and servicing a body of institutional records, a true archive, are at more points different from than like to those confronting the keeper of a collection of miscellaneous manuscripts. The distinction between manuscript and printed material becomes unreasonable in a collection of, for example, examination questions, where the size of the course determines whether papers shall be typewritten, mimeographed, or printed. At Harvard, we annually collect from every office a copy of each form it has had printed. Of course, we keep the official reserve copy of every book which comes from the Harvard University Press.

Among manuscripts as well as printed works we insist on the same criterion of relation to the university, so we politely but firmly decline autograph letters of the Presidents Adams and Roosevelt, unless they were written while these men were students, or otherwise relate to the university.

Many colleges make a practice of keeping in their archives a copy of every work written by one of their graduates. A few such attempts in that direction at Harvard have run into insurmountable difficulties. Such a policy would require the transfer to the archives of a great part of the seventeenth and eighteenth century imprints now in the Treasure Room-most of the Mather items, for example. Indeed, an attempt to collect the works of Harvard professors failed, for not only was the number of such volumes enormous, but many of them were so costly and so much in demand by the reading public that we 
could not afford to withdraw them from circulation by embalming them in the archives. From the point of view of theory, we were unable to see that Harvard authorship was a sufficient common denominator to justify building a collection of books upon it. We do make an exception in the matter of a collection of the reprints of articles written by professors, which we keep for the span of their authors' lives chiefly because no one else does or takes the trouble to catalog them. Upon the author's death, his pamphlets are bound up together and transferred to the general library.

\section{Biographical Material}

The same problems of inclusion or exclusion presented themselves when we faced the question of collecting biographical material relating to Harvard men. In general we can afford shelf space and cataloging time only to the biographies of men, graduates or not, who are known chiefly for their Harvard connection, or who have been during the productive part of their lives, Harvard employees. One turns naturally to the archives for a biography of a Harvard professor or of Bob Lampoon, but not for a life of President Hayes. We do, however, have a file with a folder for each graduate in which we drop such clippings and other ephemera as are saved nowhere else. When a man becomes important enough to fill such a folder, we begin to ignore him, for we know that someone else will take care of his biography. Nine tenths of the biographical enquiries which come to us are for unusually obscure men.

We regard a man's private correspondence and other personal papers as biographical material, and we keep those of men whose biographies we would keep.
We ask all professors to see that their personal papers come to us. Such material relating to our teachers of a century ago is a very active and useful part of our collection.

Of course, this biographical material is not strictly archival in character, for its source is not the institution itself. It is a good sample of the association material which all college archive departments collect, partly for its own sake, partly because of its value as a supplement to the records which compose the records proper. Our collection of this nonarchival Harvardiana starts off with histories of and contemporary comment on the university, followed by material relating to buildings, gifts, and other property. For convenience, duplicate sets of university publications relating to scholarships, research funds, foundations, professorships, and the like, are here grouped with clippings and other outside material relating to them.

The largest and most useful of the sections of this Harvardiana collection is that relating to the curriculum. This contains a file of the teaching announcements of the university, textbooks printed specifically for Harvard, professors' lecture notes (when decipherable), and students' notes. The file of the last begins in $167 \mathrm{I}$. Obviously such a collection could assume vast proportions, but size has not become a problem for us because of the reluctance which most former students feel to expose their youthful efforts, or lack of effort. Ideally, we would have a set of student notes for each course each year, and such a file for the courses of the great teachers of the last generation would see much use. In practice, we gather in the nicely bound and legible notes which some graduates preserve in their homes until their wives begin to complain. Eighty 
years ago a professor of English composition had his students write their daily themes on their activities, and wisely deposited the file, sealed, in the library. Other and similar files will give the social historian of the future, source material of a kind now unavailable.

\section{Section on Student Life}

Another Harvardiana section relates to student life, with the material grouped under such headings as expenses, fiction, drama, poetry, satire, concerts, music, clubs and societies, and athletics. The club records begin in $172 \mathrm{I}$. The archives of all societies which have the reason for their being in the connection of their members with Harvard are kept with the official records of the university. Such societies are a vital part of college life, but the annual change in their personnel assures the destruction of their records unless some central agency undertakes the care of them.

We keep the records of the class organizations, and store the cuts from which the pictures in their reports are printed. We have also records and photographs of student dramatic performances, some now of a considerable historical interest. In the matter of athletic material it is necessary to take a firm stand against becoming a repository for meaningless trophies. We keep one primitive football and a baseball uniform of the seventies for exhibition purposes, but otherwise we decline offers of museum material.

This, in brief, is what we have in the Harvard University Archives. How do we get it? Our first principle is that, contrary to the belief and practice of European archivists, the administrative officers who accumulate records are not the proper persons to decide what material will be of use to posterity. The decisions to keep or destroy must be at least reviewed by people with training in historical research and archive practice. For many years there have been rules issued by various administrative bodies at Harvard compelling the transfer to the archives of certain obviously important materials, such as doctoral dissertations, commencement parts, and the papers successful in prize competitions. In the case of the last, our bursar holds up the payment of the prize money until the winner can produce a certificate to the effect that he has deposited a fair copy of the paper in the college library.

\section{Ruling on Inclusion}

With the growing complexity of the university, more and more important business was transacted by departments, divisions, and committees, whose records did not ordinarily come to the archives with those of the older administrative bodies. So on February 6, 1939, the president and fellows ruled as follows:

Voted to adopt the following provisions for the preservation of official files, records, and documents:

All administrative officers of the University, including officers of instruction whose regular or occasional performance of administrative duties puts them in possession of files, records or documents pertaining to their official duties, are requested to observe the following regulations:

I. The archives of the official activities of University offices and officers are the property of the University.

2. Such property is not to be destroyed without the approval of a committee of three consisting of (a) the Secretary of the Corporation; (b) the Director of the University Library; (c) the officer in charge of the department where the papers accumulate.

3. The officer in charge of each administrative office will be the judge as to how 
long it is convenient to hold obsolete papers in his own office under his direct control.

4. All archive material, when no longer wanted in the office to which it pertains, shall be sent to the University Archives in the College Library.

Note: The term "archives" in the above statement is taken as meaning: (I) files of letters, both sent out and received; (2) records and memorandum books, ledgers, journals, cash-books, vouchers, mimeographed and similar material; and (3) the files of any matter printed for official uses.

In adopting the above regulations, the Corporation have had equally in view the importance of preserving material for the Archives and the facilities which the Archives Department of the University Library is in a position to render to all administrative officers in relieving their offices of obsolete material, in eliminating material that does not need to be preserved, and in providing space and safe custody for everything that should be preserved.

The Director of the University Library and the staff in charge of the Archives are to be at all times ready to assist officers of the University in disposing of archive material of which they wish their offices to be relieved.

No archivist, state or university, who wishes to do more than beachcomb for his materials can function properly without some such authorization as this to back him up.

Under this vote we have not approved of the destruction of any correspondence or other material containing records not duplicated elsewhere. Problems of space and handling are not serious, for no effort is made to rearrange or index modern records as they come in.

\section{Arrangement}

Fifty years ago the material in the Harvard archives was arranged on the principle of an ordinary library collection, tempered by a dim foresight of what ar- chive procedure would eventually be. For reasons which we cannot go into here, an archive cannot be arranged satisfactorily like an ordinary collection of library subject groupings. Our system was revised ten years ago by C. E. Walton, who studied archival practice in Europe. The canons of orthodox archivry are generous enough to meet all of the special problems which college archivists will meet. Thus, whereas the general rule is that the material shall be arranged according to source, reflecting the structure of the institution in the position on the shelf, it is still perfectly orthodox to make exception in the case of series, the members of which have a natural affinity although their sources may be different. In our case, theses, prize papers, and examinations are placed in their own chronological series without regard to the departments or committees to whose archives they technically belong. We have been compelled to make one serious departure from standard archival procedure because of the uniquely complex and unreasonable form of the administrative structure of the university: instead of grouping the archives of the divisions, departments, graduate schools, and other major units according to their relationships, they have been placed in a single alphabetical order.

In arranging our Harvardiana material we have profited by our own experience and that of most other collections of this type, and have made the groupings just as few and simple as practical. Material in the collections relating to buildings, gifts, scholarships, professorships, and the like, has been placed in alphabetical order, while that in collections relating to history, commencement, examinations, curriculum, athletics, and the like, is chronological. In our experience, a chronologi- 
cal arrangement has been most useful even for such collections as student fiction, poetry, and satire. By a little ingenuity in the assignment of numbers all common demands on the material can be met. Thus, with an eye to the numbers, we can at a moment's notice pull from the curriculum collection all material relating to a certain year or academic subject, or we can produce all outside comment, professors' notes, or student notes, either for any period or on any subject.

The primary function of an archive is to supply the organization whose records it keeps with information about its past. In practice this takes but a small part of the time of the staff of a college archive. At Harvard the greatest part of our work, aside from handling accessions, consists of answering outside calls for information or of guiding the researches of visiting scholars in the material in our keeping. University offices make a practice of turning over to us all questions having to do with the past of Harvard or of Harvard men. Such questions vary from that of a graduate who, while in a tuberculosis sanatorium, asked as to his lung capacity in his student days, to that of a female member of a famous family who wanted to know why her Harvard ancestor was ignored in the family genealogy. In the latter case we could do no more than quote a letter from a classmate who reported that the man in question had died, drunk, in a wheelbarrow being taken to the city jail. We were not thanked for our trouble in digging out this particular information.

\section{Outside Requests}

From outside the university we receive many requests for information as to the birth or parentage of graduates who came from regions where such records were not kept or places where they have been destroyed. Government agencies and insurance companies assume that when a boy fills out an admission application he cannot foresee any future desirability of falsifying such data. In a typical recent case, a woman wrote us that a friend of hers, the widow of a Harvard man, was destitute and suffering from want, although she would be entitled to a certain pension if it could be proved that her husband had been an American citizen. It took us but a few minutes to find the record, which the pension agency accepted at sight. F.B.I. agents are frequent visitors; we never know why but we always hope for the best.

We have a comfortable reading room in which our material may be consulted and where most of the printed Harvardiana may be charged out. Naturally the use of the archival material is restricted; you can imagine what a happy hunting ground the records of the deans' office would be for the reporters of sensational newspapers. The general rule is that the portions of the archives less than fifty years old may be consulted only by the proper officials of the university, and that the portions more than fifty years old may be made available for serious and useful research. Certain portions, notably some of the club and committee papers are under seal for a longer period. Although the archives, as distinguished from the Harvardiana collection, cannot be used as a quarry for doctoral dissertations, each year some eighty scholars are given access to portions of it in order to complete research done elsewhere. Half of these scholars are working on literary biography, so a very common object is to find the list of library books charged out by the man being investigated. The staff of 
the archives is always glad to consult the older records in order to find the answers for simple and specific questions.

\section{Year's Statistics}

Our statistics for the past year may give you some idea of the activity of the collection and the uses to which it is put. From these figures are excluded the questions answered by mail (about one a day), those answered by telephone (perhaps two a day), and the fairly frequent use of records by university officers for official purposes. Excluding this group, the total number of daily users for the year past was 2756 . On the average, nine different individuals each day applied for material to be used in the reading room or charged out. Much the most active collection was that of doctoral dissertations, which were consulted nearly two thousand times. Next most popular was the biography group, of which the publications of the classes were the most active part. The third most active group was the university records, which were consulted for nonofficial purposes less than three hundred times. The fourth most popular group was the prize papers; the fifth was the collection relating to the curriculum; the sixth, the student and official publications; and the seventh, the manuscripts and pamphlet reprints of the professors.

Since the reorganization of the Harvard archives on this basis and the establishment of an adequate staff in adequate quarters, the use of the collection has increased about tenfold. Today we answer in a minute and without undue effort, questions which a few years ago went unanswered, or in the answering involved many hours of research.

There are few places in the academic world where a college librarian can obtain better returns in terms of services rendered than he can for a little money and time spent on the archives of his institution. 